\title{
Effect of Immunological Responses of Baladi and Shami Does on Mortality Rate of their Offsprings during Post-Partum Period Nahed M. Farid ${ }^{1}$; N. H. Ibrahim ${ }^{2}$; Mona M. EL-Tonsy'; M. T. Badawy ${ }^{3}$ and Noura A. Essa ${ }^{3}$ ${ }^{1}$ Zoology department, Faculty of Science, Al - Azhar University, Egypt. \\ ${ }^{2}$ Animal and poultry production department, Faculty of Agriculture, Beni-Suef University, Egypt. \\ ${ }^{3}$ Animal and Poultry physiology Department, Animal and Poultry Division, Desert Research Center, Egypt
}

\section{ABSTRACT}

The main goal of the present experiment is to scrutinize the effect of the maternal immunity on their kids and it's relation to neonatal mortality in Baladi and Shami goat's kids during post-partum period (1st month post-partum). This study was conducted at the Ras Sudr Research Station of the Desert Research center, South Sinai Governorate, Egypt. Fifty clinically healthy adult, 18 months old, estrus synchronized does of two breeds of goats were grouped in two groups according to their breed. The first group contained 25 Baladi does (21.27 kg average body weight) and the second group contained 25 Shami does (35.35 kg average body weight). All dams of both groups were naturally mated. All kids were left with their mothers during the study period (one month) and fed only with colostrum and maternal milk. White blood cells (WBCs) and its differential count, serum immunoglobulin M (IgM) and interleukin 6 (IL-6) concentrations were determined in both dams groups at pre-partum and post-partum and in their kids at the first month postpartum. Dead kids were dissected and spleens were prepared for histopathological studies. Results demonstrated that, Baladi dams showed insignificant increase in WBCs as compared to Shami does. It was obvious that, Baladi does showed insignificant increase in neutrophils and monocytes and insignificant decrease in lymphocytes in comparison with Shami does. Concerning physiological status, significant changes were observed among WBCs and its differential count of Baladi and Shami does during experimental period. Kid's WBCs and lymphocytes were insignificantly higher in Shami kids than in Baladi kids, while neutrophils and monocytes were insignificantly lower in Shami kids. Concerning post-partum days, there was a significant increase in the values of WBC, monocytes and neutrophils throughout the 30 -days post-partum in both kids groups. The present study revealed that serum IgM was significantly higher in Baladi does $(0.91 \mathrm{mg} / \mathrm{ml})$ than in Shami does $(0.40 \mathrm{mg} / \mathrm{ml})$ by a percentage of $127.5 \%$. IgM level was significantly increased during pregnancy status and the high level was recorded in late gestation $(0.75 \mathrm{mg} / \mathrm{ml})$. Maternal breed indicated a significant effect on kid's serum IgM concentration. IgM was significantly higher in Baladi kids $(0.27 \mathrm{mg} / \mathrm{ml})$ than in Shami kids $(0.11 \mathrm{mg} / \mathrm{ml})$ by a percentage of $145.45 \%$. Serum IgM concentrations significantly increased during neonatal period. The overall mean for IL -6 was significantly higher in Shami does than in Baladi does by a percentage of $65.63 \%$. Concerning the influence of physiological status, IL -6 level increased significantly at post-partum in Shami does while pregnancy period had no significant effect on IL -6 concentration in both breeds . The overall mean for IL-6 was significantly higher in Shami kids $(27.22 \mathrm{pg} / \mathrm{ml})$ than in Baladi kids $(9.58 \mathrm{pg} / \mathrm{ml})$ by a percentage of $184.13 \%$. Serum IL-6 showed a significant reduction during neonatal period in kids on 0, 7, 14, 21 and 28 days, respectively. Histological alterations of kid's spleen revealed depleted, atrophied and necrotic lymphoid follicles as well as increase of collagen fibers.In conclusion, results revealed that both Shami and Baladi goats were adapted to the cold stress and the tolerance of Baladi goats to cold stress was much higher than Shami goats under the same condition due to increase in white blood cells, neutrophils, monocytes, serum IgM as compared to Shami does. Also, maternal immunity plays an indispensable role in the defense procedure of neonates against neonatal infections especially in Baladi goats, until its own immune system is primed and produces a defensive level of resistance. In addition, Shami and Baladi goats seemed to be similar in histological alterations of kid's spleen however, mortality rate in Shami goat's kids was higher.

Keywords: goat kids, breed, WBCs, IgM, IL- 6, spleen histopathology.

\section{INTRODUCTION}

Neonate are usually endangered by several risk influences mainly on neonatal diseases, disarranges of noninfectious etiology or by parasitic infection or obsessive conditions of microbial, which may lead to high rate of death due to weak or less developed immune system at this critical period of life span (Fragkou et al., 2010). Approximately $10 \%$ of the neonatal lambs can die immediately after parturition because of several factors and this signals death of almost half of all pre-weaning lambs (Dwyer, 2008).

Variations in hematological parameters could be due to differences in breed, age, parity, sex, species, blood collection methods, animal housing and reproductive cycle with normal pathological and physiological status, and estrous cycle phase (Alavi-Shoushtari et al., 2006). Physiological status and foetal number affect total red blood cells count especially lymphocyte and neutrophil percentages (Habibu et al., 2014). In this respect, Obidike et al. (2009) reported a higher lymphocyte percentage during post-partum period.

Several authors indicated a relationship between hematological parameters and immunity. In goats, WBCs count of kids increased in relative to an development of the immunological system during 14 days post-partum after receiving the immunoglobulins from colostrum, acquired a passive immunity (Quigley et al., 2001; Jeffcott, 2008). During the $7^{\text {th }}$ day of age, neutrophils are the dominant leukocytes in the kids, whereas by about week 2 of age leukocytes became dominant (Kramer, 2000). In newborns, natural suckling, the higher values of leukocytes which can be inferred as natural adaptation of the immune system to the immunoglobulin transported from the mother (Guedes et al., 2010). In this way, Ashour et al. (2015) showed an increase in WBCs by increasing lamb age to 30 days after birth. Also, sex and age influenced the WBCs values of lambs and kids, being higher in female kids than in male.

Parental immunoglobulins play a vital part in the defense mechanism of neonates against early diseases, until its individual immune system is informed and makes a protective level of immunity. Ideally, parental immunity should be transferred in utero to their fetuses so that they are brought into the world endangered against microorganisms. However, placental barricades in ruminants do not allow the passage of immunoglobulins from dams to neonates, and therefore it has to be completely dependent on antibodies arriving via colostrum (Tizard, 1992). Many workers noted a 
relationship between the immunization, pregnancy and lactation. Reynolds and Griffin (1990) showed that the immunoglobulin $\mathrm{M}$ levels (IgM) increased in reaction to bovine serum albumin during gestation. Secondary immunoglobulin G1 titers were significantly decreased in late gestation and during lactation whereas the lower immunoglobulin levels G2 were unchanged by gestation. Immunoglobulins form an essential part of the immunological activity found in colostrum and milk. They were central to the immunological link that occurs when the mother transferences passive immunity to their kids (Butler and Kehrli , 2005; Brandtzaeg ,2010). In goats, IgM in milk was constant throughout the reproductive cycle $(0.2 \mathrm{mg} / \mathrm{ml})$, even though a slight increase $(0.4 \mathrm{mg} / \mathrm{ml})$ was obvious at the colostrum period (Ismail and Yasuhiru, 2015). Neonatal kids and lambs have three dangerous periods related to their immune system improvement during the neonatal period: colostrum feeding, milk feeding, and weaning. Management in these critical times affects final animal performances (Massimini et al., 2007; Mastellone et al., 2011). The ingestion of colostrum by the offspring of ruminants has an important role in passive immune transfer of neonates (Hernández -Castellano et al., 2014) as they are born hypogammaglobulinemic. For this reason, animals developing under an artificial management system need to be fed, by flask, a sufficient amount of colostrum during their first week of age to attain adequate passive immune transfer and increase future efficiency (Morales-delaNuez et al., 2011).

The maternal protected system is a critical contestant in the establishing and preservation of pregnancy and successful birth (Guerin et al., 2009; Munoz-Suano et al., 2011) and is capable to utilize quality control over the establishment and progression of pregnancy (Robertson, 2010).

Cytokines play a key role in bi-directional communication between the neuron-endocrine and immune systems (Dugue and Leppaènen , 2000). Cytokines such as interleukin 6 is now well recognized for its role in the severe phase inflammatory reaction which is measured by production of a variety of hepatic proteins termed acute phase proteins (e.g., fibrinogen and complement 1 -antitrypsin). In addition to its role in the dangerous phase response, IL-6 is important for the development of specific immunologic responses. IL-6 induces differentiation of stimulated, but not resting, B cells (Taga et al., 1987) terminating in production of immunoglobulin (Ambrosino et al., 1990). IL-6 stimulates transmission of thymic and peripheral $\mathrm{T}$ cells and, in cooperation with IL-1 (Lotz et al., 1988), stimulates T cell differentiation to cytolytic-T cells and motivates natural killer cells (Renauld et al., 1989).

The spleen is the largest secondary lymphoid tissue including about $25 \%$ of the body's lymphocytes and starts immune responses to blood antigens (Kuper et al., 2002; Balogh et al., 2004). This function is attributed to the white pulp which frames the central arterioles. The white pulp is combined of three sub-compartments: the per-arteriolar lymphoid sheath, the follicles, and the peripheral zone.

The main aim of this study is to scrutinize the effect of maternal immunity of goats on neonatal kid's mortality in Baladi and Shami breeds.

\section{MATERIALS AND METHODS}

The present study was conducted at the Ras Sudr Research Station of the Desert Research center, South Sinai Governorate, Egypt during the period from February to March 2017.

Animals and housing system:

Fifty clinically healthy adult does, 18 months old, were divided in to two groups according to their breed. The first group contains 25 Baladi does $(21.27 \mathrm{~kg}$ average body weight) and the second group contains 25 Shami does (35.35 kg average body weight). Animals were housed in semi open shaded pens. They were free from internal and external parasites. All does were estrus synchronized and naturally mated. All kids were left with their mothers during the study period (one month from February to March 2017) and fed only on colostrum and maternal milk.

Feeding system and management:

Animals were fed twice a day at 08:00 and 14:00 h on Berseem hay and concentrate feed mixture to cover their nutrient requirements during different physiological status according to Kearl (1982). Chemical compositions of feed stuffs were determined according to A.O.A.C. (1990) and presented in Table (1).

Table 1. Chemical composition of feed stuffs on DM basis.

\begin{tabular}{llllllll}
\hline Ingredient & DM & OM & CP & EE & CF & NFE & Ash \\
\hline
\end{tabular}

Berseem hay $\quad 85.186 .8512 .091 .3627 .5745 .8313 .15$

Concentrate

feed mixture

91.4288 .6115 .613 .0116 .3353 .6611 .39

DM: dry matter, OM: organic matter, CP: crude protein, EE: ether extract: CF: crude fiber, NFE: nitrogen free extract.

\section{Climatic conditions}

The prevailing climate is distinguished by long hot summer, short cool winter, low rainfall and high evaporation rate. The climatic elements of South Sinai station are collected from central laboratory for agricultural climate site.

During the experimental time, average air temperature (ATOC) and relative humidity ( $\mathrm{RH} \%)$ were continuously recorded using a hygro-thermometer. The temperature-humidity index (THI) was then calculated according to Piccione et al. (2011) with the following equation:

\section{where:}

$$
\text { THI }\left({ }^{\circ} \mathrm{C}\right)=\text { tbs }-(0.55-0.55 \varphi / 100)(\text { tbs }-14.4)
$$

$$
\text { tbs = dry-bulb temperature }\left({ }^{\circ} \mathrm{C}\right) \text {, }
$$

$\varphi=$ Relative Humidity (\%).

Blood sampling:

The first blood samples were withdrawn once from all does of each breed at 8 a.m. pre-mating, pre-partum and post-partum (on day 0, 7, 14, 21 and 28). About $10 \mathrm{ml}$ of blood were collected from the jugular vein of each doe in vacuum tubes to prepare serum for IgM and IL-6 analyses and in other tubes containing ethylene diamine tetra acetic acid (EDTA) for white blood cells and their differential counts. Also, blood samples of kids were performed at 0 (a few hours after the colostrum intake), 7, 14, 21 and 28 of age. About $5 \mathrm{ml}$ of blood were collected of each breed for white blood cells and their differential counts in whole blood and determining concentration of IgM and IL-6 in blood serum with the same technique of does. 
The blood tubes were centrifuged at $3000 \mathrm{rpm}$ for $10 \mathrm{~min}$ after standing at room temperature for $20 \mathrm{~min}$, and the serum samples were stored in a freezer at $-20{ }^{\circ} \mathrm{C}$ until analyzed for subsequent biochemical analyses.

White blood cells and their differential counts were counted in blood using complete blood counter (CBC, Model (HA-Vet. Clinding, Belgium). Concentration of immunoglobulin $\mathrm{M}$ (IgM) was determined in blood serum and colostrum using chemical kits (Abbott Laboratories Company, USA), while interleukin 6 (IL-6) was determined in blood serum using goat IL-6 ELISA Kit, Cat.No: MBS025544.

Histological samples:

Dead kids were dissected immediately and small samples of spleen tissues were taken, fixed in $10 \%$ neutral buffered formal saline at PH 7.0 for 5 days, dehydrated in ascending grades of alcohol, cleared in benzyl and embedded in paraffin wax with a melting point between 55 and $56{ }^{\circ} \mathrm{C}$ for 4 hours. Sections from each group were cut at $5 \mu \mathrm{m}$, mounted on albumenized slides and stained with Hempatoxylin and Eosin (Drury and Wallington, 1976)) for normal histological study and Masson trichrome (Carson, 1990) for collagen observations.

\section{Statistical analysis}

The obtained data were statistically analyzed as two-way repeated measurements of analysis of variance (ANOVA) according to simplified linear model using statistical software Minitab 12.1 (SAS, 2004). The observed significant differences among means were set at $(\mathrm{P}<0.05)$ level according to Duncan (1955).

\section{RESULTS AND DISCUSSION}

\section{Climatic conditions:}

The environmental conditions during the first month of kids' life are given in Figure (1). It could be concluded that the new born kids suffered cold stress where AT ranged between 15 to $180 \mathrm{C}$ with high $\mathrm{RH} \%$ (60 $-70 \%$ ) and the THI increased to reach 17.23. Celi et al. (2008) stated that the survival of the neonate depends on rapid adaptation to new environmental conditions.

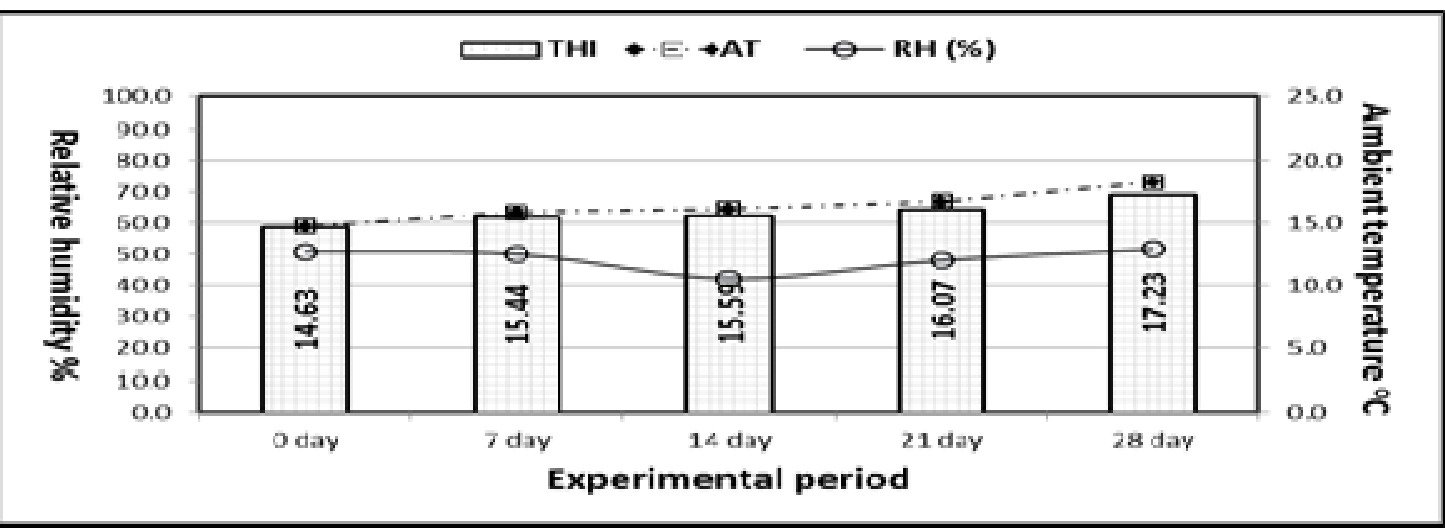

Figure 1. Graphical representation of the ambient temperature, temperature humidity index (THI) (expressed in ${ }^{\circ} \mathrm{C}$ ), and relative humidity $(\%)$, recorded during the first month of kids' life

Kidding rate of does and mortality rate of kids:

Results in Table (2) revealed higher kidding rate of does and mortality rate of kids in Shami than in Baladi does. It is of interest to note that increasing mortality rate of Shami kids was associated with higher kidding rate and continued mortality during neonatal interval from $1^{\text {st }}$ to $4^{\text {th }}$

wk of age as compared to mortality in kids of Baladi breed during the $1^{\text {st }}$ two weeks of age. This finding could be attributed to differences in maternal immunity of each breed (will be discussed in this study) and/or improper environmental conditions.

Table 2. Kidding and mortality rates of Baladi and Shami goat's kids during neonatal period

\begin{tabular}{|c|c|c|c|c|c|c|c|c|c|c|c|c|c|c|}
\hline \multirow{3}{*}{ Breed } & \multirow{3}{*}{ Sex } & \multirow{3}{*}{$\begin{array}{l}\text { Total } \\
\text { live-born } \\
\text { kids }\end{array}$} & \multirow{3}{*}{$\begin{array}{l}\text { Sex } \\
\text { ratio } \\
\%\end{array}$} & \multirow{3}{*}{$\begin{array}{l}\text { Fecundity } \\
\text { rate }(\%)\end{array}$} & \multicolumn{8}{|c|}{$\begin{array}{l}\text { kids died during neonatal period and its percentage of } \\
\text { total live-born kids }\end{array}$} & \multirow{2}{*}{\multicolumn{2}{|c|}{$\begin{array}{l}\text { Total } \\
\text { mortality } \\
\text { rate \% }\end{array}$}} \\
\hline & & & & & \multicolumn{2}{|c|}{$1^{\text {st }}$ week } & \multicolumn{2}{|c|}{2 nd week } & \multicolumn{2}{|c|}{$3^{\text {rd }}$ week } & \multicolumn{2}{|c|}{$4^{\text {th }}$ week } & & \\
\hline & & & & & $\mathbf{N}$ & $\%$ & $\mathbf{N}$ & $\%$ & $\mathbf{N}$ & $\%$ & $\mathbf{N}$ & $\%$ & $\mathbf{N}$ & $\%$ \\
\hline \multirow{3}{*}{ Baladi } & 오 & 21 & 53.85 & \multirow{3}{*}{$156 \%$} & 2 & 9.52 & 1 & 4.76 & 0 & 0.0 & 0 & 0.0 & 3 & 14.29 \\
\hline & , & 18 & 46.15 & & 4 & 22.22 & 2 & 11.11 & 0 & 0.0 & 0 & 0.0 & 6 & 33.33 \\
\hline & Total & 39 & 100.0 & & 6 & 15.38 & 3 & 7.69 & 0 & 0.0 & 0 & 0.0 & 9 & 23.08 \\
\hline \multirow{3}{*}{ Shami } & 우 & 38 & 61.29 & \multirow{3}{*}{$248 \%$} & 7 & 18.42 & 4 & 10.53 & 2 & 5.26 & 1 & 2.63 & 14 & 36.84 \\
\hline & $\hat{\sigma}$ & 24 & 38.71 & & 8 & 33.33 & 6 & 25.00 & 4 & 16.67 & 3 & 12.50 & 21 & 87.50 \\
\hline & Total & 62 & 100.0 & & 15 & 24.19 & 10 & 16.13 & 6 & 9.68 & 4 & 6.45 & 35 & 56.45 \\
\hline
\end{tabular}

White blood cells and their differential counts in Baladi and Shami does:

Baladi does showed insignificantly slight increase in white blood cells count (WBCs) and their fractions, except percentage of lymphocytes when compared to

Shami does at pre- and post-partum times. (Fig.2). These results agreed with Mohammed et al. (2016), who found that, WBCs of Damascus does were apparently lower than the other breeds (Black Aardi, White Aardi and Barbari), however this difference was not significant. It was obvious 
that, Baladi does showed insignificantly an increase in percentage of neutrophils and monocytes, and a decrease in lymphocytes in comparison with Shami does (Fig. 1).

Concerning the effect of physiological status in this study, pregnant-lactating does in both breeds had higher $(\mathrm{P}<0.05)$ WBCs compared with dry does (pre-mating. Also, percentages of neutrophils and monocytes increased $(\mathrm{P}<0.05)$ pre-mating as compared to post-partum period, while lymphocytes percentage showed an opposite trend $(\mathrm{P}<0.05)$

In accordance with the present results, (Bamerny, 2013) found that neutrophil: lymphocyte ratio increased significantly $(\mathrm{P}<0.05)$ during the latter two weeks of gestation and post-partum periods as compared to pre-
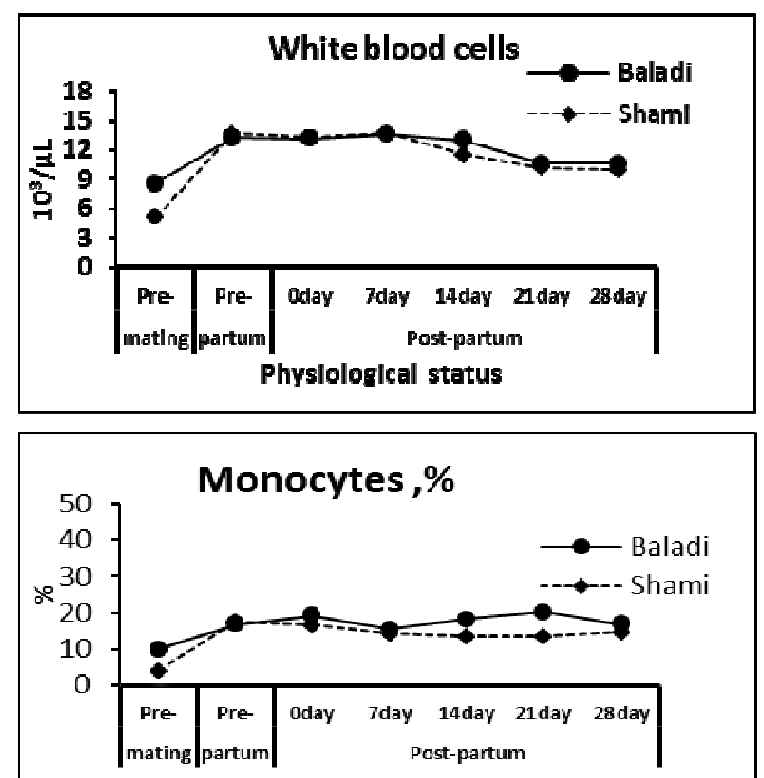

Physiological status mating period in female Meriz goats. In Baladi does, leucocytes increased on day of parturition (Azab and Abdel-Maksad, 1999). On the other hand, reports suggested no effect of physiological status and gender on total leucocyte count (El-Sherif and Assad , 2001; Iriadam, 2007). However, Chaudhari and Mshelia (2006) stated that lowest total leucocyte count was recorded during pregnancy, while the highest count was obtained during dioestrus (non-pregnant) in bitches.

Generally, stress stimulates the adenohypophysis to secrete adrenocorticotropic hormone $(\mathrm{ACTH})$, which in turn induces the adrenal cortex to produce glucocorticoids implicated in the mobilization of neutrophils from body pool into the marginal circulation (Adenkola et al., 2009).
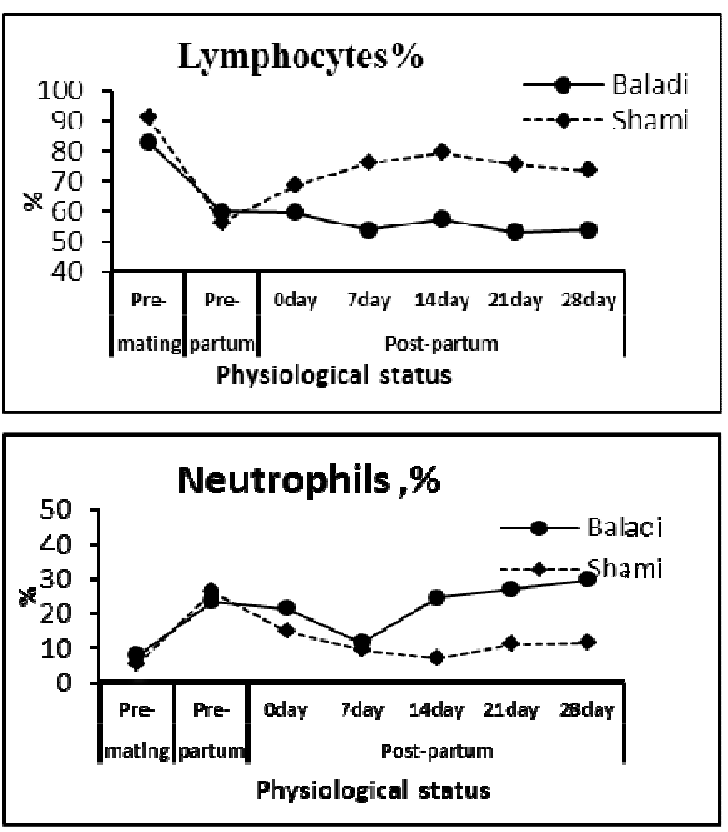

Figure 2. Change in WBCs count $\left(\mathbf{x 1 0}^{3} / \mu \mathrm{L}\right)$, and percentages of lymphocytes, monocytes and neutrophils in Baladi and Shami does during pre-and post-partum periods.

White blood cells and their differential counts of Baladi and Shami kids:

The present results (Figure 3) revealed that WBCs and lymphocytes percentage were insignificantly higher, while monocytes and neutrophils percentages were insignificantly lower in Shami than in Baladi kids.

Concerning the post-partum changes, there was increase $(\mathrm{P}<0.05)$ in the mean values of WBCs, monocytes and neutrophils in both breeds throughout the 30-days post-partum. Lymphocytes count increased $(\mathrm{P}<0.05)$ $(85.84,89.96$ and $86.15 \%)$ from 0 up to 14 days of age and then a considerable decrease $(\mathrm{P}<0.05)$ was observed during the next weeks (80.32 and $79.11 \%$ ) as illustrated in Fig. (2). Similarly, Zumbo et al. (2011) found that, WBCs increased significantly in kids during the post-partum days. Saddiqi et al. (2011) found that there was changes $(\mathrm{P}<0.05)$ in the percentages of neutrophils, lymphocytes and monocytes, whereas WBCs remained the same throughout the 30-days post-partum in Kajli lambs.

It was reported that WBCs of the offspring showed a rising value in relation to a development of the immunological system during 14 days post-partum after receiving the immunoglobulins from colostrum, acquired a passive immunity (Quigley et al., 2001; Jeffcott, 2008). In earlier researchers conducted on calves, the significant variation of WBCs was assigned to high concentration of cortisol that, just in the foetus, increased during the final days of intrauterine life and decreased progressively after the birth, for about 11-20 days; WBC increase was significant during weaning time the (Mohri et al., 2007 and Hoar and Myers, 2007). It was well established that during the first week of life, neutrophils were the dominant WBCs in the kids, whereas by about week 2 of age the lymphocytes became dominant (Kramer, 2000). 

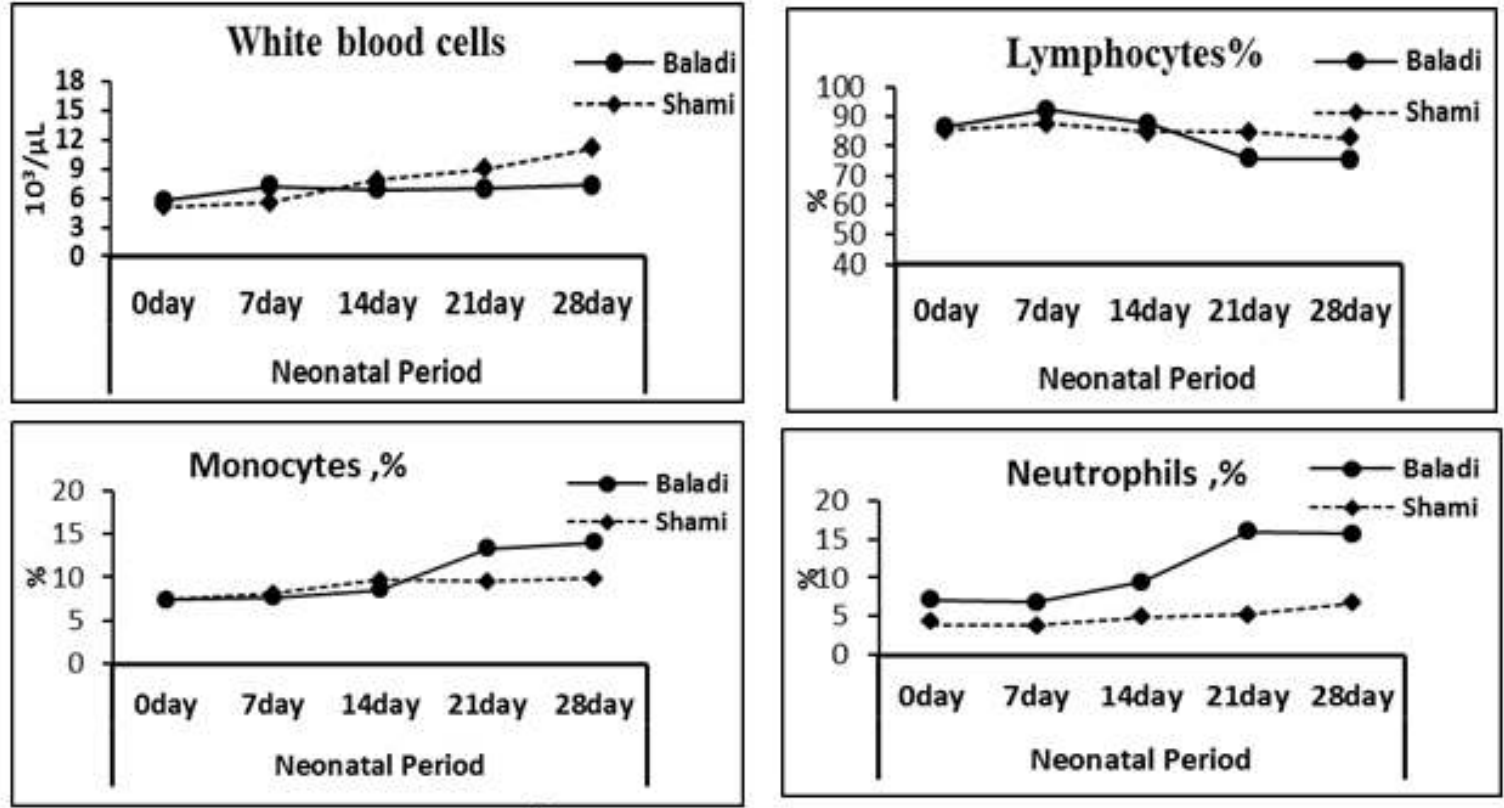

Figure 3. Change in $\overline{\mathrm{WBC}}$ s count $\left(\mathrm{xi0}^{3} / \mu \mathrm{L}\right)$, and percentages of lymphocytes, monocytes and neutrophils in Baladi and Shami kids during neonatal period.

Immunoglobulin M (IgM) concentration of Baladi and Shami does:

Overall mean of IgM concentration in serum was higher $(\mathrm{P}<0.01)$, while IL-6 concentration was lower $(\mathrm{P}<0.01)$ in blood serum of Baladi than in Shami does by about 127.5 and $65.63 \%$, respectively. . Overall mean of IgM concentration significantly $(\mathrm{P}<0.05)$ increased during pregnancy up to 7 days after kidding, and then significantly $(\mathrm{P}<0.05)$ decreased up to 28 days after kidding. However, overall mean of IL- 6 showed fluctuated trend of changes, being significantly $(\mathrm{P}<0.05)$ the highest on day 7 after kidding and the lowest at pre-partum period (Table 3).

Table 3. Mean values of immunoglobulin M (IgM) and interleukin 6 (IL-6) concentrations of Baladi and Shami does during the experimental period.

\begin{tabular}{lcc}
\hline Variable & IgM mg/ml & IL-6 pg/ml \\
\hline Effect of goat breed: & & \\
Balai & $0.93^{\mathrm{a}}$ & $16.62^{\mathrm{b}}$ \\
Shami & $0.41^{\mathrm{b}}$ & $29.68^{\mathrm{a}}$ \\
SEM & $0.01^{* *}$ & $0.08^{* *}$ \\
Effect of sampling time: & & \\
Pre-mating & $0.53^{\mathrm{e}}$ & $18.60^{\mathrm{e}}$ \\
Pre-partum & $0.75^{\mathrm{b}}$ & $16.45^{\mathrm{g}}$ \\
After birth & $0.80^{\mathrm{a}}$ & $17.50^{\mathrm{f}}$ \\
7 d after birth & $0.83^{\mathrm{a}}$ & $29.30^{\mathrm{a}}$ \\
14 d after birth & $0.69^{\mathrm{c}}$ & $25.95^{\mathrm{b}}$ \\
21 d after birth & $0.59^{\mathrm{d}}$ & $23.85^{\mathrm{d}}$ \\
28 d after birth & $0.55^{\mathrm{e}}$ & $25.00^{\mathrm{c}}$ \\
& 0.14 & 0.16
\end{tabular}

Effect of interaction between breed and sampling time:

Significance $\quad * * \quad * *$

a, b.......g: Means denoted within the same column for each effect with different superscripts are significantly different at $P<0.05$.

NS: Not significant $(\mathrm{P} \geq 0.05)$. ** Significant at $\mathrm{P}<0.01$

Effect of interaction between breed and sampling time on IgM concentration was not significant, reflecting similar trend of change in IGM level at pre- and postpartum times, being higher in Baladi than in Shami goats. However, this interaction effect was significant $(\mathrm{P}<0.01)$ on IL- 6 concentration, reflecting trend of increase in IL-6 level in Shami does versus a decrease in Baldi does during pre-partum period, however, an opposite trend of changes were observed during post-partum times (Fig. 4).

Many researchers observed the relationship between immunization, pregnancy and lactation. In this respet, Reynolds and Griffin (1990) showed that the levels of immunoglobulin $\mathrm{M}$ (IgM) increased and continued in response to bovine serum albumin during pregnancy. Also, the observed increase in IgM concentration after 7 days of kidding was proved in ewes by Basim and Abed (2015), who reported a significant increase in IgM concentration in pregnant and lactating ewes in comparison with nonpregnant and non-lactating groups.

Interleukin 6 (IL-6) concentrations of Baladi and Shami does:

Cytokines are the intercellular messengers of the immune system and closely contribute in many sides of gestation. Vast arrays of cytokines are present in gestational tissues and studies in cytokine showed that several factors influence the course of gestation and the health of the kids after birth (Ingman and Jones, 2008). Cytokines such as (IL-1 $\beta$ ), IL-6, IL-10, tumor growth factor beta (TGF- $\beta$ ) and leukemia inhibition factor (LIF) are important for embryo growing, while both IL-6 and LIF are important for elongation of embryo and placentation (Rahman, 2002; Rahman et al., 2004). The reproductive hormones supposed to interact and adjust these cytokines in the uterus of the ewe (Rahman, 2002). The maternal sheltered system is a dangerous contestant in 
the establishing and maintenance of pregnancy and successful birth ( Munoz-Suano et al., 2011) and is able to use quality control over the establishment and advancement of gestation (Robertson, 2010). For most of mid-pregnancy an anti-inflammatory environment reigns, obliging the type 1 immune partition and sustaining the oppressive regulatory cells that are an assurance of gestation tolerance (Guerin et al., 2009). In late pregnancy a pro-inflammatory environment again arises to set the scene for parturition (Romero et al., 2006 and Christiaens et al., 2008).

Based on these results, immunity parameters, in term of IgM concentration in blood serum in Baladi does increased during early stage of post-partum period, being the highest on day 7 of post-partum period and higher in Baladi than in Shami does However, similar trend was observed for IL-6 concentration in Shami, but IL-6 level in Baldi does showed gradually slight decrease pre-mating up to 28 days of post-partum period (Fig. 4). In relation with mortality rate, the observed higher IgM and lower IL-6 concentrations, as a maternal parameters, in Baldi does may suggest increasing immunity in Baldi than in Shami kids via transporting IgM to milk of kids, then increasing viability of Baladi kids. However, increasing IL-6 concentration in Shami doess may reflect some factors of environmental stress on Shami does (Table 3).
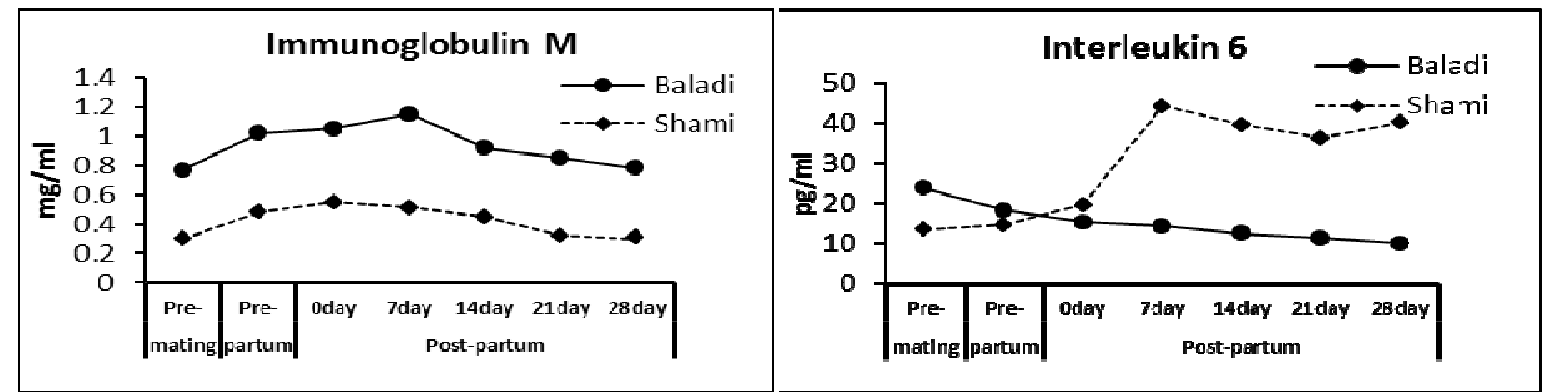

Figure 4. Change in IgM and IL-6 levels in Baladi and Shami does pre-mating (Pre-M), pre-partum (Pre-P) and on days of post-partum (0-28 d).

Immunoglobulin M (IgM) concentration of Baladi and Shami kids during neonatal period:

One of the most essential immune variables is the immunoglobulin concentration (mainly IgG and IgM). The present study showed a significant effect of maternal breed (Baladi and Shami) on kid's serum IgM concentration (Table 4). The overall mean for IgM was significantly higher $(\mathrm{P}<0.01)$ in Baladi kids $(0.27 \mathrm{mg} / \mathrm{ml})$ than in Shami kids $(0.11 \mathrm{mg} / \mathrm{ml})$ by a percentage of $145.45 \%$. Goat kids showed an IgM concentration of $1.49 \mathrm{mg} / \mathrm{ml}$ at birth (Rodriguez et al., 2009) while Logan et al. (1972) observed low IgM concentrations in neonatal calves. The variation between the results may be attributed to different IgM methodologies (ELISA vs. radial immune diffusion) or differences between species. Serum IgM concentrations were increased significantly during neonatal period and the overall means were $(0.10,0.15,0.18,0.23$ and $0.28 \mathrm{mg} / \mathrm{ml})$ on $0,7,14,21$ and 28 days respectively. In disagreement, Rodriguez et al., (2009) reported that plasma IgM concentrations were highest on day 0 in goat kids.

Selk (1998) found that, in the last 5 weeks of late pregnancy, IgA, IgG, and IgM were synthesized by plasma cells in the sub mucosa of the udder epithelium, and at the same time IgGs taken from blood by transudation began to concentrate in the secretions of the udder by inflowing the gland tissue through pinocytosis. In many neonatal animals, colostrum is the main foundation of immunoglobulins and other proteins, essential for the life (Constant et al., 1994). The grade of passive immunization after colostrum consuming differs not only on the intestinal capacity to absorb large molecules, but also on the availability of colostrum and its immunoglobulin concentration.

These factors are subject to a lot of individual differences and may be assumed by time and method of delivery, parity and breed of the mother. (Weaver et al. 2000).

Rodriguez et al. (2009) distinguished that newborn kids fed on a larger amount of IgM in colostrums had a greater IgM concentration in serum. Moreover, Stott and Fellah (1983) detected a quadratic relationship between the amount of IgM in colostrum and plasma IgM concentrations in calves. Conferring to the results of Herninde-Castellano et al. (2015), colostrum foundation (goat vs. sheep) and timing of the first colostrum feeding (2 $\mathrm{h}$ vs. $14 \mathrm{~h}$ after birth) did not affect IgM concentrations during the experimental period.

Table 4. Mean values of immunoglobulin M (IgM) and interleukin 6 (IL-6) concentrations of Baladi and Shami goat's kids during neonatal period.

\begin{tabular}{|c|c|c|}
\hline Variable & IgM mg/ml & IL-6 pg/ml \\
\hline \multicolumn{3}{|c|}{ Effect of goat breed: } \\
\hline Balai & $0.27^{\mathrm{a}}$ & $9.58^{\mathrm{b}}$ \\
\hline Shami & $0.11^{\mathrm{b}}$ & 27.22 \\
\hline SEM & $0.002 * *$ & $0.077 * *$ \\
\hline \multicolumn{3}{|c|}{ Effect of sampling time: } \\
\hline After birth & $0.10^{\mathrm{e}}$ & $21.80^{\mathrm{a}}$ \\
\hline $7 \mathrm{~d}$ after birth & $0.15^{\mathrm{d}}$ & $17.25^{\mathrm{c}}$ \\
\hline $14 \mathrm{~d}$ after birth & $0.18^{\mathrm{c}}$ & $17.40^{\mathrm{c}}$ \\
\hline $21 \mathrm{~d}$ after birth & $0.23^{\mathrm{b}}$ & $17.20^{\mathrm{c}}$ \\
\hline $28 \mathrm{~d}$ after birth & $0.28^{\mathrm{a}}$ & $18.35^{\mathrm{b}}$ \\
\hline SEM & 0.004 & 0.121 \\
\hline \multicolumn{3}{|c|}{ Effect of interaction between breed and sampling time: } \\
\hline Significance & $* *$ & ** \\
\hline
\end{tabular}



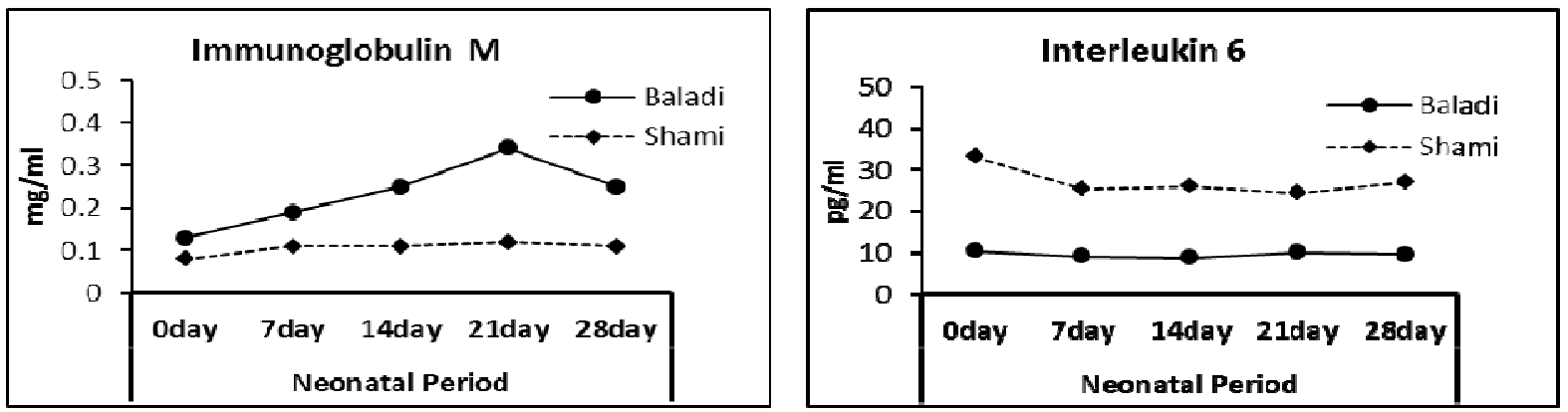

Fig. 5. Change in IgM and IL-6 levels in Baladi and Shami goat's kids during neonatal period.

Interleukin 6 (IL-6) concentrations of Baladi and Shami goat's kids during neonatal period.

The present results revealed that there was a significant effect of breed (Baladi and Shami) on kid's serum IL-6 concentration (Table 4). The overall mean for IL-6 was significantly higher $(\mathrm{P}<0.01)$ in Shami kids (27.22 $\mathrm{pg} / \mathrm{ml})$ than in Baladi kids $(9.58 \mathrm{pg} / \mathrm{ml})$ by a percentage of $184.13 \%$. Serum IL-6 showed a significant reduction during neonatal period and the overall means were $(21.80,17.25,17.40,17.20$ and $18.35 \mathrm{pg} / \mathrm{ml})$ on 0,7 , 14, 21 and 28 days respectively. The decrease of cytokine production might be a result from a reduction in the total number of immune cells, as immune cells exert their belongings through the cytokines production (Penny et al., 1999). In both breed, the level of IL-6 decreased suddenly from after birth $(21.8 \mathrm{pg} / \mathrm{ml}$; on average $)$ to the 7 days of age $(17.25 \mathrm{pg} / \mathrm{ml}$; on average). However, the decrease was more obvious in Shami kids (from 33.20 to $25.4 \mathrm{pg} / \mathrm{ml}$ ) than in Baladi kids (from 10.4 to $9.1 \mathrm{pg} / \mathrm{ml}$ ), which resulted in significant interaction $\mathrm{Br}$ X D (Fig. 5).

At birth the controlled uterine environment finishes, and the consequent $24 \mathrm{~h}$ signify a critical change phase between the foetal functions and those of the neonates. The survival of the neonate varies on rapid adaptation to new conditions which requires the formation of cardiovascular, respiratory, metabolic and thermoregulation mechanisms that are essential for survival (Celi et al., 2008). High IL-6 levels in kids immediately after parturition may be due to sudden exposure to extra-uterine cold stress. Rhind et al. (2001) create that cold stress enhanced IL-6, I L-2 and tumor necrosis factor (TNF)-a cytokine levels.

All living organisms react to stress changes in the environment in various ways. Activation of the stress system clues to peripheral and behavioural changes to improve the ability of the organism to regulate homeostasis and increase its abilities for survival (Chrousos, 2000). Exposure to a dangerous environment such as cold and heat is a form of stress experienced by all organisms (Kanayama et al., 1999). Cytokines play a key role in bidirectional diffusion between the neuron-endocrine and immune systems. The relationship between hormones and cytokines during thermal stress may influence immune homeostasis in response to environmental encounters (Dugue and Leppaènen, 2000). Stress affects numerous sides of immune function, depending on the nature and duration of the stress (Dhabhar, 2003).

\section{Hisopathological results of spleen}

The histological examination of splenic tissue samples of dead kids revealed depletion, atrophy and necrosis of lymphoid follicles in spleen of dead kids on one day of age (Figs6-7), in stillbirth kid (Fig. 8) and in kids on day 5 of age (Fig. 9). From another angel, in all dissected Baladi and Shami kids, spleen showed diffusion of fibrous connective tissue surrounding the congested interstitial blood vessel (Fig. 10). These histological changes in the spleen of dead kids at different ages indicated splenic pathological lesions leading to immunity disorders in kids and consequently increase mortality rate.

Spleen is the secondary lymphoid tissue and its micro construction is split by a trabecular connective tissue which is comprised of a red and white pulp. The red pulp (RP) is specified in exclusion of old cells from the blood with the help of reticular fibers, fibroblasts and macrophages. The white pulp is the splenic lymphoid component and it is prearranged around a central arteriole where is possible to distinguish per arteriolar lymphoid cover, the marginal zone (MZ) and the lymphoid follicles (LF). The T lymphocytes are found in the PALS, whereas $\mathrm{IgD}+\mathrm{IgM}+\mathrm{B}$ cells are located in the germinal centers. The spleen construction is important for the advance of immune responses to different types of antigens in addition to maintain the memory B cell series (Mebius and Kraal, 2005). Spleen is a key tissue for the improvement of natural and obtained immune responses. Splenic macrophages and dendritic cells are frequently activated because of the blood influx that produces along many antigens from the circulation. This continuously activation of APC is important for T cell motivation, explosion and cytokine production. After spleenectomy, IFN-gamma levels are usually decreased (Maioli et al., 2007), and this can be one of the causes for the enhanced sensitivity to some infections. The spleen integrity is essential to reserve $\mathrm{B}$ cell repertory, reactive oxygen species production, and maintenance of memory B cells (De Porto et al., 2010).

Relatively short-term exposure of pigs to cold increased standard concentrations of the stress-related hormones ACTH and cortisol and elevated proinflammatory cytokines in the liver and spleen (Frank et al., 2003). The exposure to cold affected significantly lymphatic tissues. Thus, the size of those tissues should inhibit the immune response. 


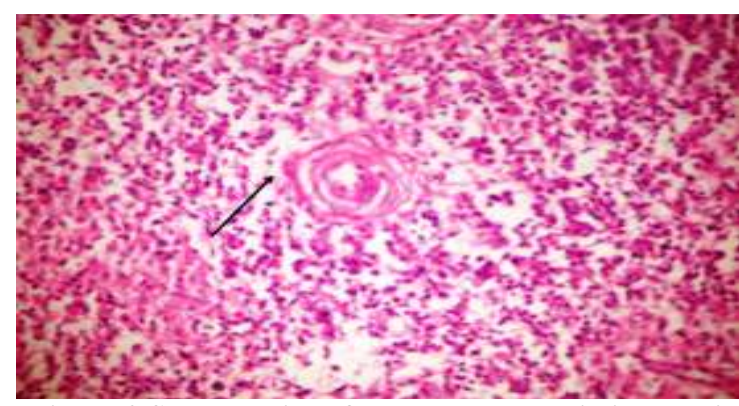

Figure 6. Spleen section of one day old Baladi kids showing depleted and necrosed lymphoid follicles (arrow) (H\&E X 400).

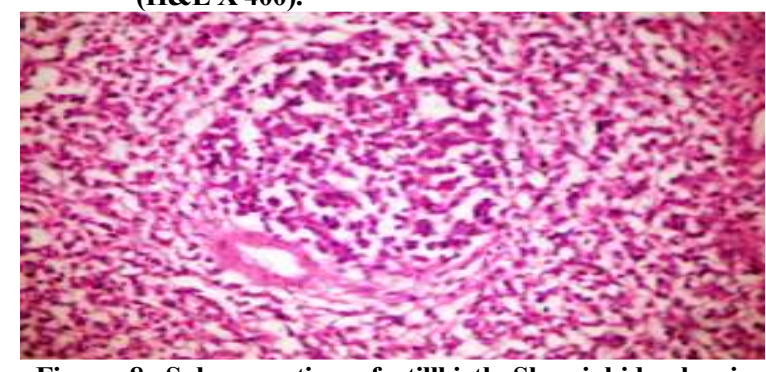

Figure 8. Spleen section of stillbirth Shami kids showing pathological effect in term of depleted lymphoid follicles (arrow) (H\&E X 400).

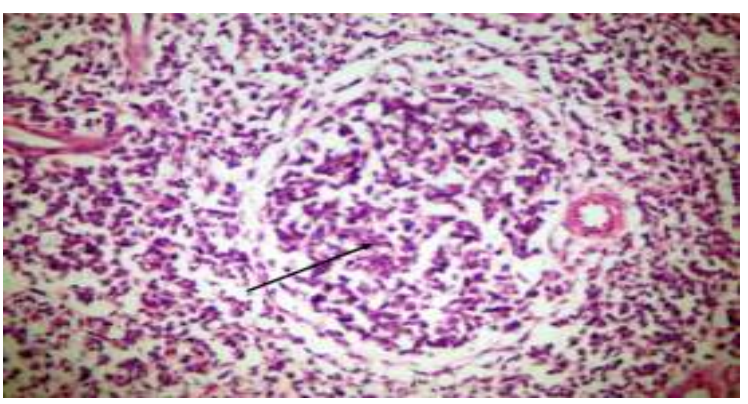

Figure 7. Spleen section of one day old Shami kids showing depleted and atrophied lymphoid follicles (arrow) (H\&E X 400)

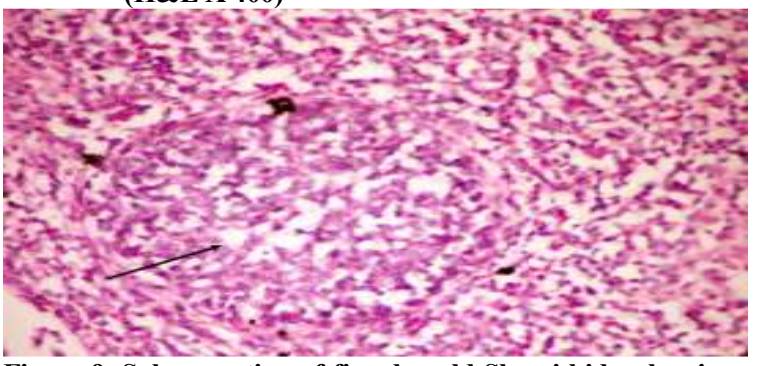

Figure 9. Spleen section of five day old Shami kids showing necrosis of lymphoid follicles (arrow) 400).

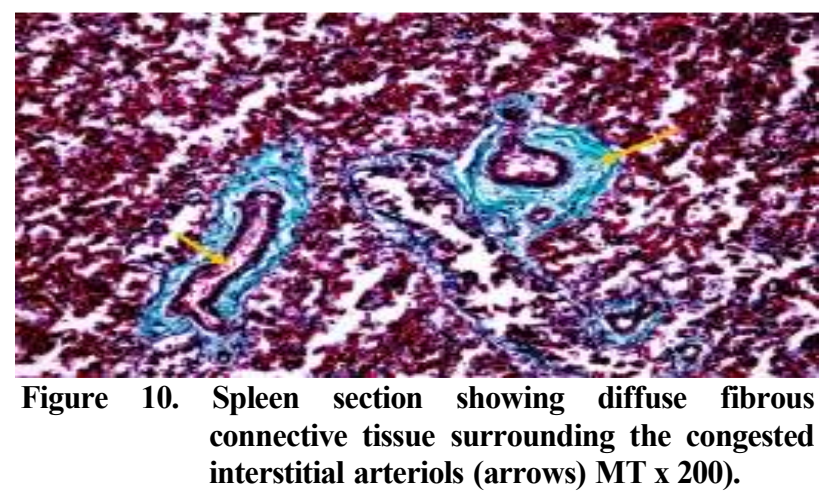

\section{CONCLUSION}

It can be concluded that maternal immunity plays an indispensable role in the defense mechanism of neonates against neonatal diseases, until its own immune system is primed and produces a protective level of immunity.

\section{REFERENCES}

Adenkola, A.Y.; Ayo, J.O.; Sackey, A.K.B. and Adelaiye, A.B. (2009): Hematological and serum biochemical changes in pigs administered with ascorbic acid and transported by road for four hours during the harmattan season. J. Cell Anim. Biol., 3: 21-28.

Alavi-Shoushtari, S.M.;Asri-Rezai, S. and Abshenas, J. (2006): A study of the uterine protein variations during the estrous cycle in the cow: a comparison with serum proteins. Anim. Rep. Sci., 96 (1 - 2): $10-20$.
Aluvihare, V.R.; Kallikourdis, M. and Betz, A.G. (2004): Regulatory $\mathrm{T}$ cells mediate maternal tolerance to the fetus. Nat. Immunol. , 5: 266-271.

Ambrosino, D. M.; Delaney, N. R. and Shamberger, R. C. (1990): Human polysaccharide-specific B cells are responsive to pokeweed mitogen and IL-6. J .Immunol., 144:1221-1226

Ashour, G .; Neama, A. A. ; Dessouki, S. M. and Shihab, O. H. (2015): Blood hematology, metabolites and hormones in newborn sheep and goat from birth to weanin. Inter. J. of Advan. Res. , 3(7): 1377-1386.

Association of Official Analytical Chemists (A.O.A.C.) (1990): Official Methods of Analysis. 15th ed. Association of Official Analytical Chemists, Arlington, VA.

Azab, M.E. and Abdel-Maksad, H.A. (1999): Changes in some haematological and biochemical parameters during prepartum and postpartum periods in female Baladi goats. Small Rum. Res., 34(1): 7785. 
Balogh, P.; Horvath, G. and Szakal, A. K. (2004): Immunoarchitecture of distinct reticular fibroblastic domains in the white pulp of mouse spleen. J. Histochem. Cytochem., 52:1287-98.

Bamerny, A.O. (2013): changes in Some haematobiochemical and electrolytes parameters in female Meriz goats during pregnancy and after parturition. J. Anim. Sci., 2(1): 11-14

Basim, H. and Abed, A. (2015): The effect of pregnancy and lactation on blood biochemical and immunological values in ewes after enterotoxaemia vaccination. AL-Qadisiya J. of Vet. Med. Sci., 14 ( 1):65-68.

Brandtzaeg, P. (2010): The mucosal immune system and its integration with the mammary glands. J. Pediatr., 156, S8-S15.

Butler, J.E. and Kehrli, M.E. ( 2005): Immunoglobulins and immunocytes in the mammary gland and its secretions: In Mucosal Immunology, 3rd ed. , Elsevier Academic Press, Burlington, USA , 2: 1764-1793.

Carson,F.(1990):Histology, a self-instructional text. $1^{\text {st }}$ ed., 142-144.

Celi, P. ; Adriana, D. T.; Salvatore, C. and Paola, D.G. (2008): Effects of perinatal nutrition on metabolic and hormonal profiles of goat kids (Capra hircus) during their first day of life. Asian-Aust. J. Anim. Sci. , 21( 11): 1585 - 1591.

Chaudhari, S.U. and Mshelia, G.D. (2006): Evaluation of the haematological values of bitches in Northern Nigeria for the staging of pregnancy. Pak. J. Biol. Sci., 9 (2): 310 - 312.

Christiaens, I.; Zaragoza, D.B.; Guilbert, L.; Robertson, S.A.; Mitchell, B.F. and Olson, D.M. ( 2008): Inflammatory processes in preterm and term parturition. J. Reprod. Immunol. ,79:50-57.

Chrousos, G.P. (2000): The role of stress and the hypothalamic-pituitary- adrenal axis in the pathogenesis of the metabolic syndrome: neuroendocrine and target tissue-related causes. Int. J. Obes. Relat. Metab. Disord., 24 (2): 50-55.

Cichon, M. ; Magdalena, C.; Aneta, K. and Marek, K. (2002): Delayed effects of cold stress on immune response in laboratory mice. Proc. R. Soc. Lond. , 269: 1493-1497.

Constant, S.B.; Leblanc, M.M. ;Klapsten, E.F.; Beebe, D.E.; Leneau, H.M. and Nu-nier, C.J. (1994): Serum immunoglobulin $\mathrm{G}$ concentration in goat kids fed colostrum or colostrum substitute. J. Am. Vet. Med. Assoc., 205: 1759-1762.

De Porto, A.P.; Lammers, A.J.; Bennink, R.J.; ten Berge, I.J. and Speelman, P. (2010): Assessment of splenic function. Eur. J .Clin. Microbiol. Infect. Dis ., 29: 1465-1473.

Dhabhar, F.S. (2003): Stress, leukocyte trafficking, and the augmentation of skin immune function. Ann . N.Y. Acad. Sci.,992:205-217.
Dimitriadis, E.; White, C.A.; Jones, R.L. and Salamonsen, L.A. (2005): Cytokines, chemokines and growth factors in endometrium related to implantation. Hum. Reprod. Update ,11:613-630.

Drury,R.A. and Wallington,E.A.(1976):Carletons histological techniques. $4^{\text {th }}$ ed.London:Oxford University Press, 139-142.

Dugue, A.B. and Leppaènen, E. (2000): Adaptation related to cytokines in man: effects of regular swimming in ice-cold water. Clin. Physiol.,20: 114-121.

Duncan, D. B. (1955): Multiple Range and Multiple F Tests. Biometrics 11:1.

Dwyer, C. M. (2008): The welfare of the neonatal lamb. Small Rumin. Res. 76:31-41.

El-Sherif , M.M. and Assad, F. (2001): Changes in some blood constituents of Barki ewes during pregnancy and lactation under semi-arid conditions. Small Rumin. Res., 40:269-277.

Frank, J. W.; Carroll, J. A.; Allee, G. L. and Zanelli, M. E. (2003): The effects of thermal environment and spray-dried plasma on the acute-phase response of pigs challenged with lipopolysaccharide. J. Anim. Sci., 81:1166-1176.

Fragkou, I. A., Mavrogianni, V. S. and Fthenakis, G. C. (2010): Diagnostic investigation of cases of deaths of newborn lambs. Small Rumin. Res. 92:41-44.

Guedes, M.T.; Zacharias, F.; Couto, R.D.; Portela, R.W.; Santos, L.C.; Santos, S.C.; Pedrpza, K.C.; Pelxoto, A.P.; Lopez, J.A. and Medoca -Lima, F.W. (2010): Maternal transference of passive humoral immunity to Haemonchus contortus in goats. Vet. Immuno. Immunopath., 136:138-143.

Guerin, L.R.; Prins, J.R. and Robertson, S.A. ( 2009): Regulatory T-cells and immune tolerance in pregnancy: a new target for infertility treatment. Hum. Reprod. Update, 15:517-535.

Habibu, B.; Kawu, M.U. ; Makun, H.J. ;Aluwong, T.; Yaqub, L.S. ; Ahmad, M.S. ; Tauheed, M. and Buhari, H.U. (2014): Influence of sex, reproductive status and foetal number on erythrocyte osmotic fragility, haematological and physiologic parameters in goats during the hot-dry season. Vet. Med., 59 (10): 479-490.

Hernández-Castellano, L. E.; Almeida, A. M.; Castro, N. and Argüello, A. (2014): The colostrum proteome, ruminant nutrition and immunity: A review. Curr. Protein Pept. Sci., 15:64-74.

Herninde - Castellano, L.E.; Morales - delaNuez, A.; Sanchez - Maciaas, D.; Moreno - Indias, I.; Torres, A.; Capote, J.; Arguello, A. and Castro, N. (2015): The effect of colostrum source (goat $v s$. sheep) and timing of the first colostrum feeding $(2 \mathrm{~h} v s .14 \mathrm{~h}$ after birth) on body weight and immune status of artificially reared newborn lambs. J. Dairy Sci. ,98 :204-210.

Hoar, B.R. and Myers, D.M. (2007): Effect of an immunostimulant administered at or near weaning on weight gain and health of beef calves. Bovine Practitioner ,41:48-52. 
Ingman, W.V. and Jones, R.L. ( 2008): Cytokine knockouts in reproduction: the use of gene ablation to dissect roles of cytokines in reproductive biology. Hum. Reprod. Update ,14:179-192.

Iriadam, M. (2007): Variation in certain hematological and biochemical parameters during the peri partum period in Kilis does. Small Rumin. Res. ,73:54-57.

Ismail, H. and Yasuhiru, K. (2015): Immunological quantitation of $\mathrm{IgG}$ and $\operatorname{IgM}$ in milk and serum of the goat at different stages of the reproductive cycle . Annals of Biological Research ,6 (9):16-20.

Jeffcott, 1.B. (2008): Passive immunity and its transfer with special reference to the horse. Biology Review, 47:439-464.

Kanayama, N.; Khatun, S.; Belayet, H.; She, L. and Terao, T. (1999): Chronic local cold stress to the soles induces hypertension in rats. Am. J. Hypertens., 12:1124-1129.

Kearl, I. C. (1982): Nutrients requirements in developing countries., Utah. Agric. Exp. Stat., Utah State University, Logan, USA.

Kramer, J.W. (2000): Normal hematology of cattle, sheep and goats. In: Schalm's Veterinary Hematology, Ed. Lippincott, Williams and Wilkins, $5^{\text {th }}$ Edition. ,166: 1078-1079.

Kuper, D. F.; de Heer, E.;Van Loveren, H. and Vos, J. G. (2002): Immune System. In Handbook of Toxicologic Pathology, $2^{\text {nd }}$ ed. , Academic Press, San Diego, p: 585-646.

Logan, E. F.; Penhale, W. J. and Jones, R. A. ( 1972): Changes in the serum immunoglobulin levels of colostrum-fed calves during the first 12 weeks postpartum. Res. Vet. Sci. , 14:394-397.

Lotz, M.; Jirik, F.; Kabouridis, R.; Tsoukas, C.; Hirano, T.; Kishimoto, T. and Carson, D. (1988): B cell stimulating factor $2 /$ interleukin 6 is a costimulant for human thymocytes and T lymphocytes. J. Exp. Med., 167:1253-1258.

Maioli, T.U.; Carneiro, C.M.; Assis, F.A. and Faria, A.M. (2007): Splenectomy does not interfere with immune response to Leishmania major infection in mice. Cell Immunol., 249: 1-7.

Massimini, G.; Mastellone, V.; Britti, D.; Lombardi, P. and Avallone, L. (2007): Effect of passive transfer status on preweaning growth performance in dairy goat kids. J. Am. Vet. Med. Assoc., 231:18731877.

Mastellone, V.; Massimini, G.; Pero, M. E.; Cortese, L.; Piantedosi, D.; Lombardi, P.; Britti, D. and Avallone, L. (2011): Effects of passive transfer status on growth performance in buffalo calves. Asianaustralas. J. Anim. Sci., 24:952-956.

Mebius, R.E. and Kraal, G. (2005): Structure and function of the spleen. Nat. Rev. Immunol. , 5: 606-616.

Mohammed, S. A.; Mohammed, A. R. ; Anaam, E. O. ; Sheeba, A. and Waleed, M. A. (2016): Biochemical and hematological profile of different breeds of goat maintained under intensive production system. Afr. J. Biotechnol., 15(24): 1253-1257.
Mohri, M.; Sharifi, K. and Eidi, S. (2007): Haematology and serum biochemistry of Holstein dairy calves: Age related changes and comparison with blood composition in adults. Res. Vet. Sci., 87: 30-39.

Morales-delaNuez, A.; Moreno-Indias, I. ; SanchezMacias, D.; Capote, J. ; Juste, M. C.; Castro, N.; Hernandez-Castellano, L. E. and Arguello, A. (2011): Sodium dodecyl sulfate reduces bacterial contamination in goat colostrum without negative effects on immune passive transfer in goat kids. J. Dairy Sci., 94:410-415.

Munoz-Suano, A.; Hamilton, A.B. and Betz, A.G. (2011): Gimme shelter: the immune system during pregnancy. Immunol. Rev., 241: 20-38.

Obidike, I.R.; Aka, L.O. and Okafor, C.I. (2009): Timedependant peri - partum haematological, biochemical and rectal temperature changes in West African dwarf ewes. Small Rumin. Res., 82: 53-57.

Penny, L. A.; Armstrong, D.; Bramley, T. A.; Webb, R.; Collins, R. A. and Watson, E. D. (1999): Immune cells and cytokine production in the bovine corpus luteum throughout the oestrous cycle and after induced luteolysis. J. Reprod. Fertil., 115:87-96.

Quigley, J.D.; Strohbehn, R.E.; Kost, C.J.; O’brien, M.M. ( 2001): Formulation of colostrum supplements, colostrum replacers and acquisition of passive immunity in neonatal calves. J. Dairy Sci., 84:2059-2065.

Rahman, A. N. M. A. ( 2002): Changes in the Uterine Immune System during Pregnancy in sheep., MVSc Thesis, Department of Veterinary Science, The University of Melbourne, Melbourne, Australia: 1-140.

Rahman, A. N. M. A.; Snibson, K.; Lee C. S. and Mueesen, E. N. T. (2004): Effects of implantation and early pregnancy on the expression of cytokines and vascular surface molecules in the sheep endometrium. J . Reprod. Immunol., 64: 45-58.

Renauld, J. C.; Vink, A. and Van Snick, J. (1989): IL1 and IL6 in CTL induction-accessory signals in murine cytolytic T cell responses: Dual requirement for IL1 and IL6. J. Immunol., 143:1894-1898.

Reynolds, G. E. and Griffin, J. F. (1990): Humoral immunity in the ewe. 2. The effect of pregnancy on the primary and secondary antibody response to protein antigen. Vet. Immunol. Immunopathol., 25(2):155-166.

Rhind, S.; Castellani, J.W. and Brenner, I.K. ( 2001): Intracellular monocyte and serum cytokine expression is modulated by exhausting exercise and cold exposure. Am. J. Physiol. Regul. Integr. Comp. Physiol., 281:66-75.

Robertson, S.A. (2010): Immune regulation of conception and embryo implantation-all about quality control. J. Reprod. Immunol. ,85: 51-57. 
Rodriguez, C.; Castro, N.; Capote, J.; Morales-delaNuez, A.; Moreno-Indias, I.; Sanchez-Macias, D. and Argüello, A. (2009): Effect of colostrum immunoglobulin concentration on immunity in Majorera goat kids. J. Dairy Sci. , 92 (4): 16961701.

Romero, R.;Espinoza, J.; Goncalves, L.F.; Kusanovic, J.P.; Friel, L.A. and Nien, J.K. (2006): Inflammation in preterm and term labour and delivery. Semin. Foetal Neonatal Med. ,11:317326.

Saddiqi, H. A. ; Nisa, M.; Mukhtar, N.; Shahzad, M. A.; Jabbar, A. and Sarwar, M. (2011): Documentation of Physiological Parameters and Blood Profile in newly born Kajli Lambs. Asian-Aust. J. Anim. Sci. , 24(7): $912-918$.

SAS (2004): Statistical Analysis System , STAT/ user's guide, Release 9.1, SAS Institute, Cary NC. USA.

Selk, G. E. (1998): Management factors that affect the development of passive immunity in the newborn calf. In: Beef Cattle Handbook-2240. Extension Beef Cattle Resource Committee: 1-7.
Stelwagen, K.; Carpenter, E.; Haigh, B.; Hodgkinson, A. and Wheeler, T. T. ( 2009): Immune components of bovine colostrum and milk. J. Anim. Sci., 87(1):3-9.

Stott, G. H. and Fellah, A. (1983): Colostral immunoglobulin absorption linearly related to concentration for calves. J. Dairy Sci. ,66:1319 1328 .

Taga, T.; Kawanishi ,Y.; Hardy, T. T.; Hirano, T. and Kishimoto, T. (1987): Receptors for B cell stimulatory factor 2. J .Exp. Med., 166:967-981 .

Tizard, I. (1992): Veterinary Immunology: an introduction. $4^{\text {th }}$ ed, W. B. Saunders Company, London.

Weaver, D.M; Tyler, J.W; Van, M. D.C.; Hostetler, D.E and Barrington, G.M (2000): Passive transfer of colostral immunoglobulins in calves. J. Vet. Intern. Med. ,14: 569-577.

Zumbo, A.; Salvatore, S. ; Vanessa, M. ; Stefania, C. ; Ambra, R. d. and Giuseppe, P. (2011): Haematological profile of messinese goat kids and their dams during the first month post-partum. An. Sci. Pap. Rep., 29 (3): 223-230.

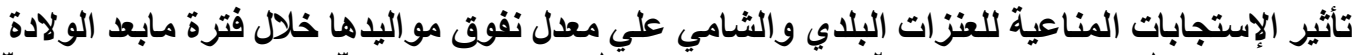

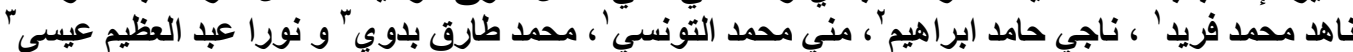

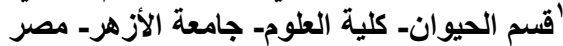

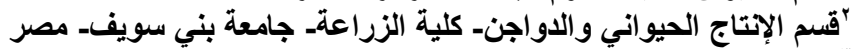

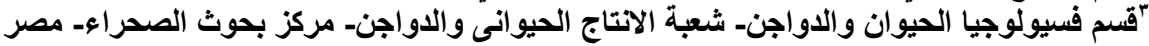

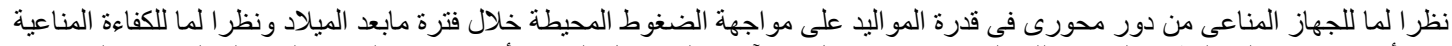

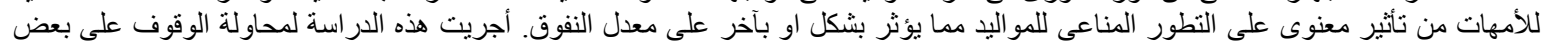

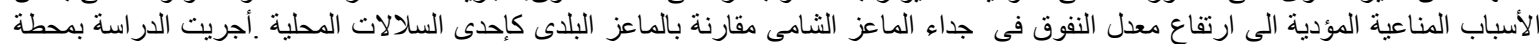

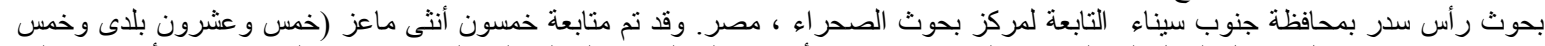

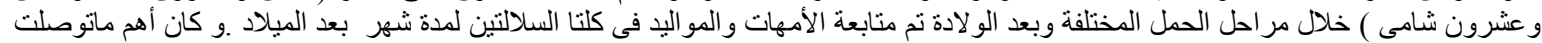

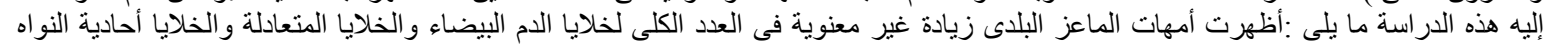

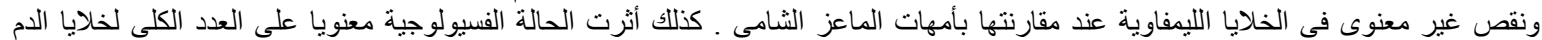

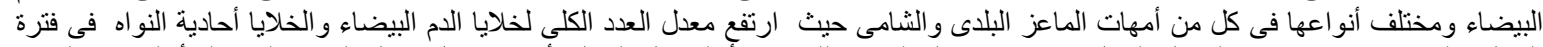

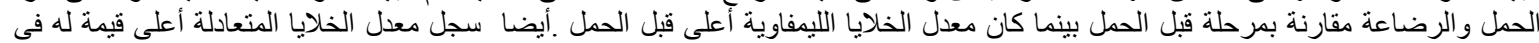

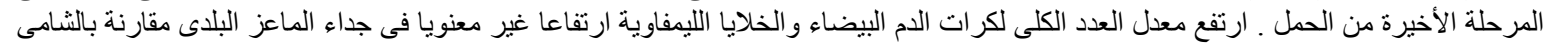

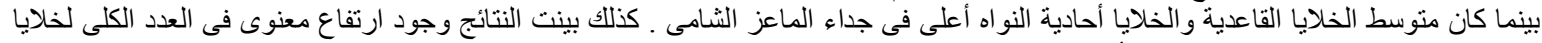

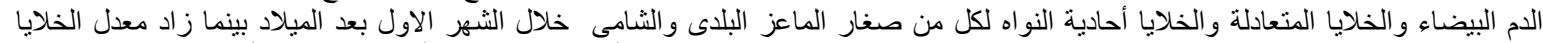

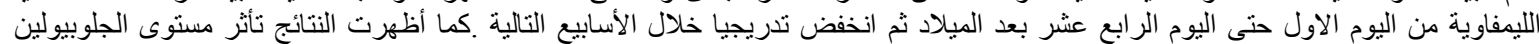

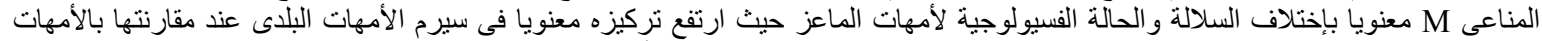

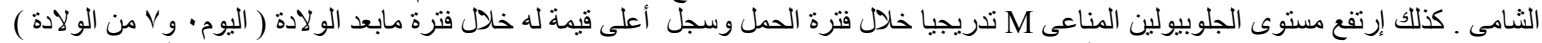

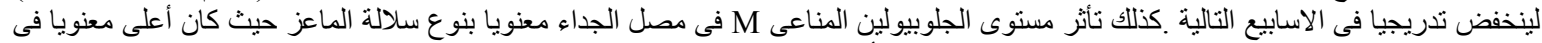

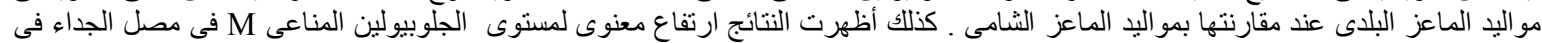

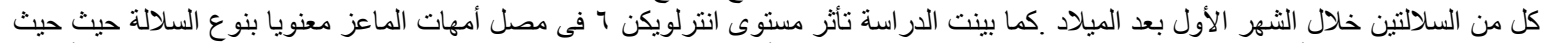

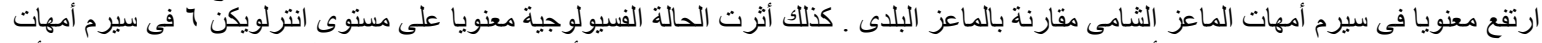

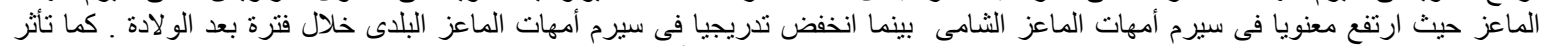

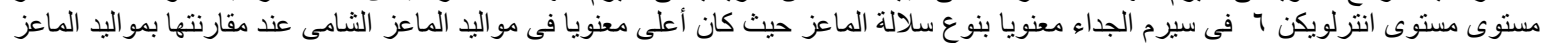

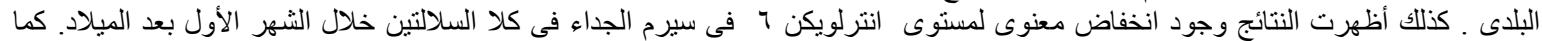

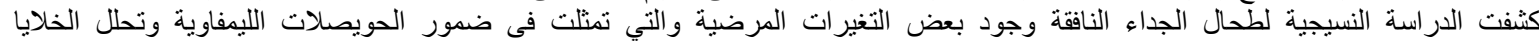
الحويصلات الليمفاوية واحتقان ونزف في الأوعية الدموية بالإضافة إلى وجود تجمعات لألياف الكو لاجين حول الأو فية الدية الدموية . 